American Journal of Agricultural and Biological Sciences 5 (1): 102-106, 2010

ISSN 1557-4989

(C) 2010 Science Publications

\title{
Species Composition, Ecological Parameters and Seasonal Changes of Planktonic Ciliates Population in Bukan Dam Reservoir
}

\author{
${ }^{1}$ A. Mohsenpour Azary, ${ }^{1}$ F. Mohebbi, ${ }^{1}$ A. Eimanifar, \\ ${ }^{2}$ A. Javanmard and ${ }^{2}$ Agamaliyev F.Q. Aliyev \\ ${ }^{1}$ Department of Ecology, Westocentral Asian Artemia Reference Center, \\ P.O. Box 368, Uremia, Iran \\ ${ }^{2}$ Department of Animal Science, Faculty of Agriculture, \\ University Putra Malaysia, 43400 UPM Serdang, Selangor, Malaysia
}

\begin{abstract}
Problem statement: Since there is no evidence to identify present species in the Bukan dam reservoir, therefore, this study was conducted to provide background for fisheries purposes. Approach: The abundance and species composition of ciliates were analyzed in the Bukan Dam reservoir (west Azerbaijan, Iran) from January to December 2007. Surface water samples were collected at monthly intervals at two different points, open water (Station 1,3) and in the shallowest area of the reservoir (Station 2,4) and examined for planktonic protozoa composition and density. Chlorophyll a was analyzed and a few ecological parameters such as dissolved oxygen, $\mathrm{pH}$, turbidity and temperature were measured. Results: Totally 50 ciliates species were found in Bukan dam reservoir. Concerning the protozoa density, a high-density period was detected from January to April with a mean number of $2.86 \times 10^{3}$ cells. $\mathrm{L}^{-1}$ protozoa at Stations 1,3 and $4.16 \times 10^{3}$ cells. $\mathrm{L}^{-1}$ protozoa at shallowest areas at stations 2, 4 thanks to disappear of phytoplankton in the winter. The summer development of protozoa was possible thanks to the development of bacteria and moderate metazooplankton densities due to the appearance of non-edible algae. The density of ciliates was low during the rest of the year. The mean number of organisms at the high-density period was approximately 4 -fold more than that obtained during the low-density one. The ciliates occurring at the highest densities were Coleps tessellates, Paradileptus elephantinus, Zosterograptus labiatus, Cyclidium citrullus. Conclusion/Recommendations: It was concluded that ciliates density have important role for saprobic condition of Bukan reservoir. Therefore, it can be recommended to determine more effective parameters for density of ciliates and management policies must be programmed in order to improve ecological condition for this reservoir.
\end{abstract}

Key words: Plankton, ciliates, Bukan reservoir, West Azerbaijan, Iran

\section{INTRODUCTION}

Bukan dam reservoir is located in south part of west Azerbaijan, with the total length of $17 \mathrm{~km}$. It has been formed by the building of the dam, $48 \mathrm{~m}$ high in 1969. The total volume of the reservoir is $650 \times 10^{6} \mathrm{~m}^{3}$ and useful volume is $486 \times 10^{6} \mathrm{~m}^{3}$ and total area is $45 \times 10^{6} \mathrm{~m}^{2}$. The complex hydrobiological examinations with monthly sampling have been taken to study the pelagic ciliates on this reservoir, because the ecological role of planktonic cilliates as trophic links between bacteria and pelagic zooplankton has been increasingly appreciated during recent years (Foissner et al., 1999). Protozoa are known to play an important role by consuming bacteria and thus reducing their numbers in environments rich in organic matter (Javornicry and Perokesova, 1963). They also consume phytoplankton (Brook, 1952) and are consumed by Cladocera, Copepoda and Rotifera (Rerk et al., 1977) in addition to being highly efficient in releasing phosphorus (Porter et al., 1979). Study of the zooplankton cycle in a marine environment, showed that protozoa act as a link in the food chain of the sea between small planktonic organisms to the large metazooplanktonic herbivores (Smetacek, 1981). Ciliates graze on autotrophic and heterotrophic pico and nanoplankton and functioning as prey for larger zooplankton, contribute to the remineralization and cycling of nutrients (Blomqvist et al., 2001; Ventela et al., 2002). They play a pivotal role in the indication of pollution degree in lakes (Sonntag et al.,

Corresponding Author: A. Mohsenpour Azary, Department of Ecology, Westocentral Asian Artemia Reference Center, P.O. Box 368, Uremia, Iran 
2002). The present investigation was undertaken to study the abundance and frequency of planktonic cilliates and some ecological parameters in deep and shallow environment of Bukan dam reservoir.

\section{MATERIALS AND METHODS}

Three samples were taken in the middle water column by means of a $5 \mathrm{~L}$ sampler (Bernatowicz, 1953), $200 \mathrm{~mL}$ of this sample was fixed immediately with $8.6 \mathrm{~mL}$ of a saturated $\mathrm{HgCl}_{2}$ solution and stained with $0.04 \%$ bromophenol blue (Pace and Orcutt, 1981). Three subsamples were counted in a chamber and examined with a microscope $(\times 100)$. Protozoa were identified according to the work by Jahn et al. (1949); Pennak (1953) and Lynn (2008). Taxonomic identifications were based mostly on Foissner et al. (1999). Additionally the following physical and chemical factors were studied: visibility, $\mathrm{pH}, \mathrm{O}_{2}$, conductivity and biogens (TN, $\left.\mathrm{PO}_{4}, \mathrm{~N}-\mathrm{NH}_{4}, \mathrm{~N}-\mathrm{NO}_{3}\right)$. Visibility, $\mathrm{pH}, \mathrm{O}_{2}$ and conductivity was determined in situ using the Secchi disc and electrode Jenway 3405 and remaining factors were analysed in the laboratory, according to Hermanowicz et al. (1976).

\section{RESULTS}

The seasonal variations of water transparency, dissolved oxygen and chlorophyll a are shown in Fig. 1. Chlorophyll a fluctuation showed two distinct phases: A period from May to Jun during which showed values higher than those observed at a period from July to October during which the opposite occurred. The maximum chlorophyll a value observed at the reservoir water was $10.39 \mu \mathrm{g} . \mathrm{L}^{-1}$ being obtained in May.

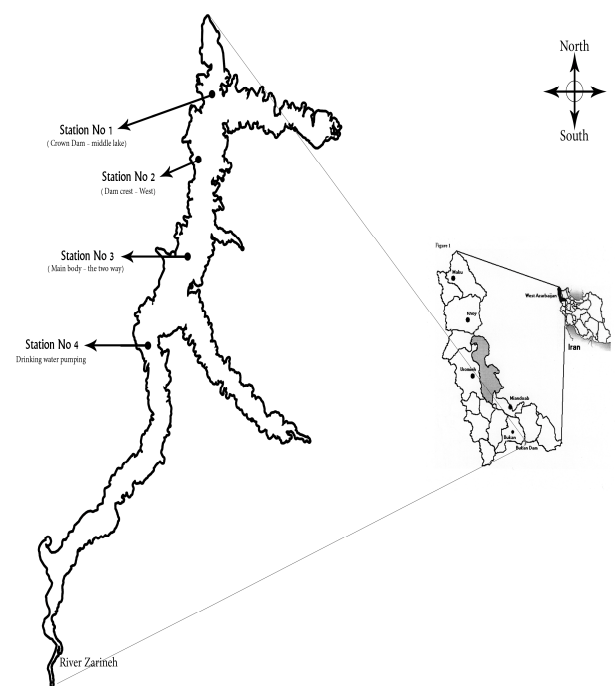

Fig. 1: Location of sampling and collection of data
Temperature and $\mathrm{pH}$ profiles at reservoir are shown in Fig. 2 and 3. The highest temperatures were recorded from July to September, with a maximum value of $27.5^{\circ} \mathrm{C}$. The minimum values were observed in February, with values of 4.8. PH was between 7.3 and 8.55 during the study period at the reservoir.

The chemical properties of water including hardness, conductivity, $\mathrm{PO}_{4}, \mathrm{TN}$ and $\mathrm{BOD}, \mathrm{N}-\mathrm{NO} 3, \mathrm{~N}-$ NH4 were different among months and their particular values are presented in Table 1. These parameters confirmed mesotrophic status of the reservoir and were similar to that observed in other mesotrophic lakes (Carlson, 1977; Wetzel, 1983).

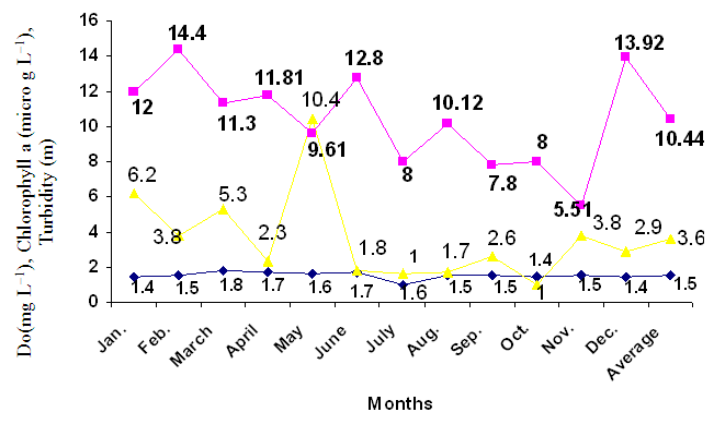

Fig. 2: Monthly variations of turbidity, dissolved oxygen and chlorophyll a

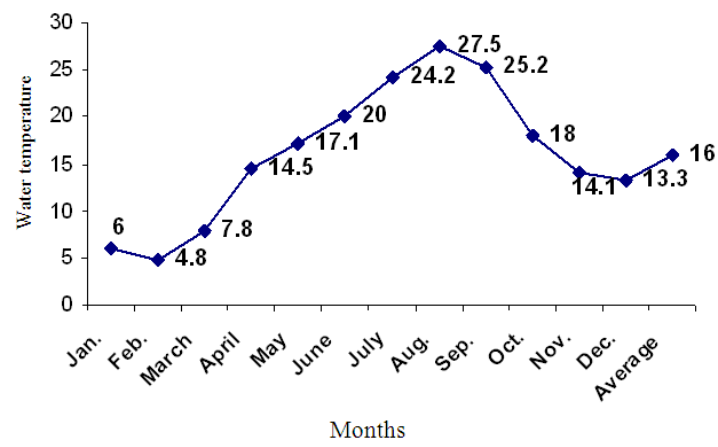

Fig. 3: Water temperature profile at Bukan reservoir2007

Table 1: Chemical properties of water on Bukan reservoir-2007

\begin{tabular}{llrlllll}
\hline & Hardness & \multicolumn{1}{c}{$\mathrm{Ec}$} & $\mathrm{PO}_{4}$ & $\mathrm{TN}$ & $\mathrm{BOD}$ & $\mathrm{N}-\mathrm{No}_{3}$ & $\mathrm{~N}^{-\mathrm{NH}_{4}}$ \\
\hline Jan. & 150.40 & 61.40 & 0.14 & 1.09 & 6.42 & 1.60 & 0.20 \\
Feb. & 159.20 & 229.80 & 0.16 & 1.58 & 2.92 & 1.13 & 0.10 \\
March & 145.71 & 281.57 & 0.06 & 1.24 & 2.65 & 1.42 & 0.15 \\
April & 156.80 & 219.00 & 0.32 & 1.62 & 1.54 & 1.67 & 0.06 \\
May & 147.00 & 212.25 & 0.22 & 1.14 & 2.51 & 1.38 & 0.03 \\
June & 158.33 & 150.10 & 0.34 & 1.19 & 1.41 & 1.00 & 0.16 \\
July & 145.67 & 48.12 & 0.37 & 1.70 & 4.77 & 1.00 & 0.23 \\
Aug. & 141.75 & 46.65 & 0.04 & 1.39 & 2.19 & 1.00 & 0.12 \\
Sept. & 161.50 & 53.79 & 0.34 & 1.10 & 6.59 & 1.60 & 0.18 \\
Oct. & 173.00 & 73.09 & 0.09 & 1.22 & 5.69 & 1.00 & 0.15 \\
Nov. & 140.40 & 230.40 & 0.11 & 1.07 & 7.37 & 1.40 & 0.26 \\
Dec. & 172.80 & 53.64 & 0.15 & 1.73 & 4.87 & 1.14 & 0.15 \\
\hline
\end{tabular}


Am. J. Agri. \& Biol. Sci., 5 (1): 102-106, 2010

Table 2: Ciliates taxa in open water and shallowest areas the Bukan reservoir

Ciliates species groups

\begin{tabular}{|c|c|c|}
\hline Kinetofragminophora & Oligohymenophora & Polyhymenophora \\
\hline Prostomatida & Hymnostomatida & Heterotrichida \\
\hline Eoleps hirtus Nitzch. & Tetrahymena pyriformis Schewiakoff. & Metopus es Mull. \\
\hline Holophrya atra Svec. & Glaucoma chattoni Corliss. & Stentor polymorphus Ehrb. \\
\hline H. hexatricha Savi. & Paramecium aurelia Ehrb. & S. roeseli Ehrb. \\
\hline Prorodon brachyodon Kahl. & $P$. caudatum Ehrb. & Condylostoma rugosum Kahl. \\
\hline P. viridis Ehrb-Kahl. & P. bursaria Focke. & Oligotrichida \\
\hline P. ovum Kahl. & Frontonia acuminate Kahl. & Halteria grandinella Mull. \\
\hline P. teres Ehrb. & F. leucas Fabr.-Dom. & Strombidium viride Stein. \\
\hline Coleps tesselatus Kahl. & F. elliptica Beard. & S. mirabile Penard. \\
\hline Haptorida & Urosentrum turbo Mull. & S. fallax Zach. \\
\hline Enchelys pupa Mull.-Ehrb. & Stokesia vernalis Wenrich. & Strombilidium gyrans (Stok.) \\
\hline Didinium nasutum Mull. & Scuticociliatida & S. velox Faur.-Fr. \\
\hline Paradileptus elephantinus (Svec.) & Pleuronema coronatum Kent. & Tintinnidium pusillum Entz. \\
\hline P. conicus Wenrich. & Cyclidium glaucoma Mull. & Tintinnopsis cylindrata Kofoid.-Campbell. \\
\hline Lacrymaria olor Mull & C. citrullus Cohn. & Hypotrichida \\
\hline Pleurostomatida & Vorticella nebulifera Mull. & Oxytricha minor Kahl. \\
\hline Litonotus lamella Ehrb. & V. campanula Ehrb. & O. pellionella Mull. \\
\hline Nassulida & - & Stylonychia mytilus (Mull.) \\
\hline Nassula citrea Kahl. & - & Euplotes patella Mull. \\
\hline Zosterograptus labiatus Kahl. & - & E. eurystomus Wrz. \\
\hline \multicolumn{3}{|l|}{ Trithigmostoma cucullalus Mull. } \\
\hline T.steini (Blochm.) & - & Aspidisca costata Duj. \\
\hline
\end{tabular}

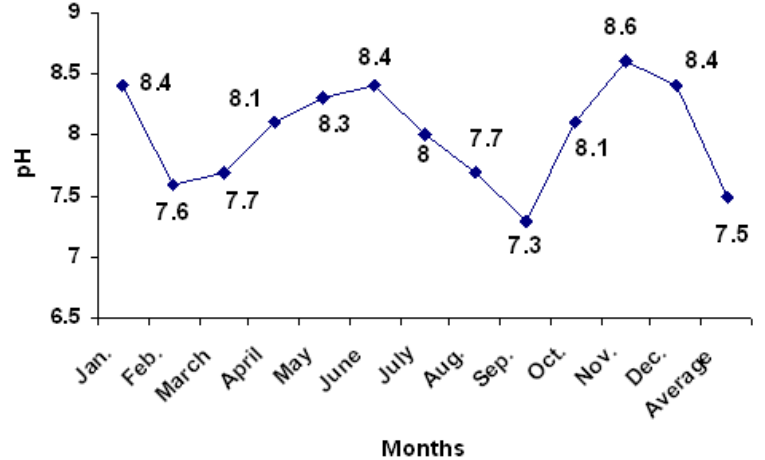

Fig. 4: $\mathrm{pH}$ profile at Bukan reservoir-2007

The composition and abundance (mean values) of the major ciliates taxa in open water and shallowest areas of Bukan reservoir are presented in Table 2 and Fig. 4.

A total number of 50 ciliates species were found in plankton samples. The most abundant species was belonged to Hymnostomatida (10 species) and the least species was belonged to Pleurostomatida (1 species). The seasonal distribution of Ciliates populations in the Bukan reservoir is presented graphically in Fig. 5 and 6. Three different periods can be observed with respect to the density of protozoa detected, i.e., a high-density period from January to April and from July to August and a low-density period from September to December.

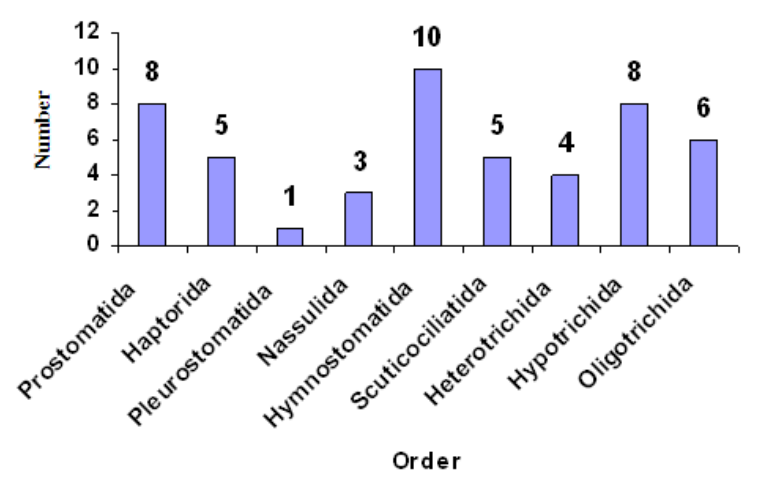

Fig. 5: Species number of Ciliates Classes at Bukan dam reservoir-2007

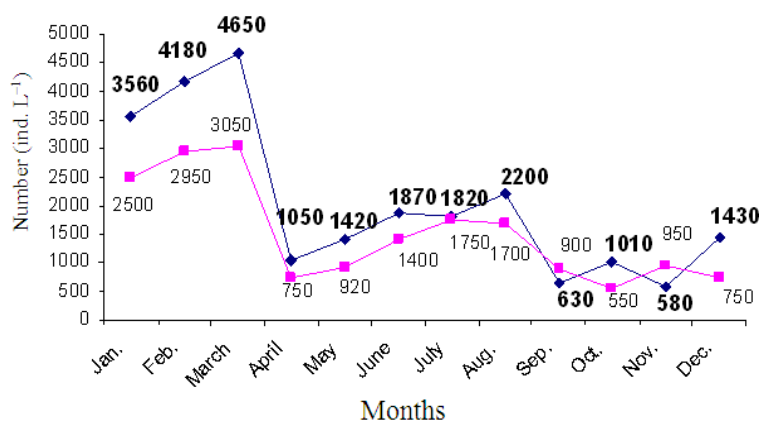

Fig. 6: Seasonal distribution of Ciliates population in the Bukan reservoir-2007 
The mean number of organisms detected during the low-density period at autumn was about 1000 protozoa $\mathrm{L}^{-1}$ at the shallowest areas and 700 protozoa $\mathrm{L}^{-1}$ at open water. During the high-density period, the mean number at the shallowest areas was about 4000 protozoa $\mathrm{L}^{-1}$ while at the open water it was 2800 protozoa $\mathrm{L}^{-1}$. Thus, during the high density period the mean number of organisms was approximately 4 fold that obtained during the low density period. The densities of ciliates showed clearly marked seasonal changes in Bukan reservoir. They fluctuated from 1 ind. $\mathrm{mL}^{-1}$ in April to 5 ind. $\mathrm{mL}^{-1}$ in March. During this period Prostomatida (Coleps tesselatus), Haptorida (Paradileptus elephantinus), Nassulida (Zosterograptus labiatus), Scuticociliatida (Cyclidium citrullus), Heterotrichida (Metopus sp.) and Oligotrichida (Strombilidium gyrans) constituted $60 \%$ of the total number of the ciliates.

\section{DISCUSSION}

Among the physico-chemical variables investigated at the Bukan Reservoir, temperature showed a pattern commonly observed in shallow and turbulent aquatic ecosystems. $\mathrm{pH}$ varied little around 7.5 and 8.5; the concentration of dissolved oxygen was between 5.75 and $14 \mathrm{mg} \mathrm{L}^{-1}$, corresponding to $65-$ $152 \%$ saturation, with the environment being well oxygenated throughout the study period. Chlorophyll a concentration, measured from Jan to Dec. 2007, was relatively low with a maximum of $10.39 \mu \mathrm{g} \mathrm{L}^{-1}$. The highest densities of planktonic protozoa in the Bukan reservoir were observed from January to April. The densities of ciliates showed clearly marked seasonal changes in the reservoir. Also the peaks in the winter and the summer were probably determined by abiotic water factors. They were observed also in other eutrophic (Takamura et al., 2000) and hypertrophic lakes (Ventela et al., 2002). Protozoan abundance tended to increase with increasing lake productivity (Beaver and Crisman, 1990). The present study clearly showed that ciliates abundance correlated with reservoirs productivity, too. The concentration of appropriate food (bacteria, nanoflagellates and algae) are probably the major regulator of abundance, biomass and diversity of planktonic ciliates (Wisckowski et al., 2001). Very high densities of ciliates in late winter in Bukan reservoir might have been caused by the phytoplankton density. It seems that with the death of these organisms there is greater decomposition and consequently, a larger number of bacteria and amount of detritus available for the protozoa, which in turn increase in density. Similar situation relating a large abundance of protozoa after the death of the phytoplankton and simultaneous bacterial growth has been previously observed in Lake Dalnee-USSR (Sorokin and Paveljeva, 1972). The small bacterivorous ciliates, mainly Scuticociliatida are typical of mesotrophic lakes individuals in each sample (Beaver and Crisman, 1990). Also omnivorous Coleps tesselatus and Vorticella sp. dominated in pelagial of lakes in $\mathrm{pH}>7$ and their importance increases with eutrophication (James et al., 1995). The highest densities occurrence of Coleps tessellates, Paradileptus elephantinus, Zosterograptus labiatus, Cyclidium citrullus in the late winter showed increasing of eutrophication in the reservoir that was happened with increased water entrance at this season. Totally, we may conclude that the Bukan dam reservoir was mesotrophic at the study period.

\section{CONCLUSION}

Totally, considering the physicochemical factors and population composition of ciliatae, we may conclude that the Bukan dam reservoir was mesotrophic at the study period.

\section{ACKNOWLADGMENT}

This research was supported by Artemia Research Center, Uremia, Iran.

\section{REFERENCES}

Beaver, J.R. and T.L. Crisman, 1990. Seasonality of plank tonic ciliated protozoa in 20 subtropical Florida lakes of varying tropic state. Hydrobiologia, 190: 127-135. DOI: 10.1007/BF00014103

Bernatowicz, S., 1953. Apparatus for Quantitative Plankton Sampling. Wszechoe wiat, pp: 127-128.

Blomqvist, P., M. Jansson, A.K. Drakare, M. Bergstrőm and A. Brydsten, 2001. Effects of additions of DOC on pelagic biota in Clearwater systems: Results from a whole lake experiment in northern Sweden. Microb. Ecol., 42: 383-394. DOI: $10.1007 / \mathrm{s} 002480000101$

Brook, A.J., 1952. Some observations on the feeding of protozoa on freshwater algae. Hydrobiology, 4: 281-293. DOI: 10.1007/BF00044348

Carlson, R.E., 1977. A trophic state index for Lakes: Limnol. Oceanogr., 22: 361-369. 
Foissner, W., H. Berger and J. Schaumburg. 1999. Identification and Ecology of Limnetic Plankton Ciliates. The Bavarian State Office for Water, ISBN: 3-930253-79-8, pp: 793.

Hermanowicz, W., W. Dozanska, J. Doilido and B. Koziorowski, 1976. Physical and Chemical Investigation Methods of Water and Sewage. Arkady, Warsow.

Jahn, T.L, E.E. Bowne and F.F. Jahn, 1949. How to Know the Protozoa? The Picture Key Nature Series Brown, Dubuque, pp: 249.

James, M.R., C.W. Burns and D.J. Forsyth, 1995. Pelagic ciliated protozoa in two monomictic, southern temperate lakes of contrasting trophic state: Seasonal distribution and abundance. J. Plankton Res., 17:1479-1500. DOI: 10.1093/plankt/17.7.1479

Javornicry, P. and V. Prokesova, 1963. The influence of protozoa and bacteria upon the oxidation of organic substances in water. Int. Rerwr Ges. Hydrobiol., 48: 335-350.

Lynn, D., 2008. The Ciliated Protozoa: Characterization, Classification and Guide to the Literature. 3rd Edn., Springer, ISBN: 13: 9781402082382, pp: 606.

Pace, M.L. and J.R. Orcutt, 1981. Relative importance of protozoans, rotifers and crustaceans in a freshwater zooplankton community. Lirnnol. Oceanogr., 26: 822-830.

Pennak, R.W., 1953. Freshwater Invertebrates of United States. The Ronald Press Company, New York, pp: 769.

Porter, K.G., M.L. Pace and 1.F. Battey, 1979. Ciliate protozoans as links in freshwater plank tonic food chains. Nature, 227: 563-565. DOI: $10.1038 / 277563 \mathrm{a} 0$
Rerk, S.G., D.C. Brownlee, D.R. Heinle, H.S. Kiing and R.R. Colweli, 1977. Ciliates as a food source for marine planktonic copepods. Microbiol. Ecol., 4: $27-40$.

Smetacek, V., 1981. The annual cycle of Protozooplankton in the Kiel bight. Mur. Biol., A3: 1-11. DOI: 10.1007/BF00394657

Sonntag, B., T. Posch, Ch. Griebler and R. Psenner, 2002. Protozooplankton in the deep oligotrophic Traunsee (Austria) influenced by discharges of sonda and salt industries. Water Air Soil Pollut. Focus, 2: 211-226.

Sorokin, Y.I. and E.B. Paveljeva, 1972. One the quantitative characteristics of the pelagic ecosystem of Dalnee lake (Kamchatka). Hydrobiology, 40: 519-552.

Takamura, N., Y. Shen and P. Xie, 2000. Species richness of protozoa in Japanese lakes. Limnology, 1: 91-106. DOI: $10.1007 / \mathrm{s} 102010070015$

Ventela, M.A., K. Wišckowski, M. Moilanen, V. Saarikari and K. Vuorio et al., 2002. The effect of small zooplankton on the microbial loop and edible algae during a cyanobacterial bloom. Freshwater Biol., 47: $\quad 1807-1819$. DOI: $10.1046 /$ j.13652427.2002.00924.x

Wetzel, R.G., 1983. Limnology. In: Michigan: Measurement of Chlorophyll-a, Youngman, R.E. (Ed.). Tech Rep TR-82 Water Research Center, State University, New York.

Wisckowski, K., A.M. Ventela, M. Moilanen, V. Saarikari and K. Vuorio et al., 2001. What factors control plank tonic ciliates during summer in a highly eutrophic lake. Hydrobiologia, 43-57. DOI: 10.1023/A:1017592019513 